Vol. I No. 01Hal. $48-53$

15 - Januari 2018

\title{
Upaya Meningkatkan Hasil Belajar Siswa Dengan Menerapkan Pendekatan Kontekstual Dalam Pembelajaran IPA Pada Materi Pokok Bioteknologi di Kelas XI-1 SMP Negeri 5 Stabat TP.2016/2017
}

\author{
Rusli \\ Guru SMP Negeri 5 Stabat \\ NIP. 196809302000121001
}

\begin{abstract}
ABSTRAK
Drs. Rusli, M.Pd., NIP. 196809302000121001, Master of SMP Negeri 5 Stabat, "Efforts to Improve Student Learning by Implementing Contextual Approach in Science Learning on Basic Matter of Biotechnology in Class IX-1 SMP Negeri 5 Stabat T.P. 2016/2017 ". Problem formulation: Is the application of contextual learning can improve student learning outcomes on science learning biotechnology main subject in class IX-1 SMP Negeri 5 Stabat T.P. 2016/2017. The purpose of this research is to know the improvement of student learning outcomes through the application of contextual approach on science learning biotechnology main subject in class IX-1 SMP Negeri 5 Stabat T.P. 2016/2017. The research procedure is carried out through two cycles with four stages: 1) planning; 2) action; 3) observation; 4) reflection; The unresolved problem is reflected as the teaching improvement material of the next cycle. The results of the classroom action research show the students' learning outcomes by applying contextual approaches have increased. This is seen in the average grade 74 (incomplete category) in the first cycle to 83 (complete category) in cycle II and the percentage of learning completeness classically increased from $53 \%$ in the first cycle to $87.5 \%$ in cycle II
\end{abstract}

\section{PENDAhuluan \\ 1. Latar Belakang}

Pendidikan adalah hak setiap anak agar anak dapat mewujudkan cita-citanya dan menjadi manusia yang berpenghidupan lebih tinggi artinya pendidikan merupakan salah satu faktor yang sangat penting dalam meningkatkan sumber daya manusia. Menurut Ki Hajar Dewantara pendidikan adalah tuntutan di dalam hidup tumbuhnya anak-anak, adapun pendidikan adalah menuntut segala kekuatan kodrat yang ada pada anak-anak itu, agar mereka sebagai manusia dan sebagai anggota masyarakat dapat mencapai keselamatan dan kebahagiaan setinggi-tingginya. Anak yang mendapatkan pendidikan yang baik akan menciptakan manusia yang siap menghadapi kemajuan pengetahuan dan teknologi dengan bijak serta mampu mewujudkan tujuan-tujuan pendidikan yang diharapkan. Salah satunya adalah tujuan pendidikan nasional yakni berkembangnya potensi peserta didik agar menjadi manusia yang beriman dan bertakwa kepada Tuhan yang Maha Esa, berakhlak mulia, sehat, berilmu, cakap, kreatif, mandiri, dan menjadi warga negara yang demokratis serta bertanggung jawab. Jelas terlihat pentingnya proses pendidikan bagi setiap anak. Pembelajaran IPA merupakan salah satu mata pelajaran di sekolah menengah pertama yang merupakan program untuk menanamkan dan mengembangkan pengetahuan, keterampilan, sikap dan nilai ilmiah pada diri peserta didik serta menanamkan rasa mencintai dan menghargai kebesaran Tuhan yang Maha Esa. Pembelajaran IPA merupakan proses belajar yang menyangkut hubungan antara makhluk hidup dengan lingkungannya. Suatu proses belajar yang selalu berhubungan dengan aktivitas dunia nyata. Sehingga terjadinya interaksi antara siswa dengan siswa, siswa dengan guru dan siswa dengan lingkungannya. Dengan demikian, siswa diharapkan mampu menyatu dengan lingkungannya dan yang terpenting adalah siswa mampu memecahkan persoalan IPA di lingkungannya. Pembelajaran IPA diharapkan dapat meningkatkan pemahaman siswa serta mengembangkan kemampuan kognitif, afektif, dan psikomotorik. Menurut Nasution 
(2000: 94) "Pelajaran akan lebih menarik dan berhasil, apabila dihubungkan dengan pengalaman-pengalaman di mana anak dapat melihat, meraba, mengucap, berbuat, mencoba, berfikir, dan sebagainya". Dengan kata lain, belajar akan lebih bermakna jika anak mengalami langsung apa yang dipelajarinya dengan mengaktifkan lebih banyak indera daripada mendengarkan guru menjelaskan. Oleh sebab itu seluruh potensi dan bakat yang dimiliki siswa perlu didorong agar berkembang secara optimal. Peran guru menjadi kunci keberhasilan dalam misi pendidikan dan pembelajaran di sekolah selain bertanggung jawab untuk mengatur, mengarahkan dan menciptakan suasana kondusif yang mendorong siswa untuk melaksanakan kegiatan di kelas. Namun pada kenyataannya, dalam pembelajaran yang berlangsung guru lebih banyak berceramah di depan siswa sementara siswa pun hanya duduk dan mendengarkan tanpa memahami konsep-konsep IPA yang diajarkan. Proses pembelajaran yang berlangsung hanya berpusat pada guru, bahkan ada beberapa siswa yang bermain-main saat proses pembelajaran berlangsung. Bila suasana ricuh terjadi di kelas guru mengeluarkan suara keras menyuruh siswa mendekap tangan dan mengunci mulut. Hilang sudah potensi sains yang seharusnya dirasakan siswa sebagai pengalaman yang bermakna baginya. Padahal pengalaman bermakna akan memunculkan pengalaman belajar yang baik untuk mengembangkan kemampuan berpikir yang dapat di gunakan untuk menjelaskan permasalahan yang dapat ditemukan dalam kehidupannya sehari-hari. Seiring dengan perkembangan di dunia pendidikan, guru diharapkan mampu bijak dalam mengambil keputusan, baik pada saat merencanakan pembelajaran ataupun adanya masalah dalam kegiatan pembelajaran, maka permasalahan yang muncul adalah bagaimana upaya guru untuk meningkatkan hasil belajar siswa dengan pendekatan yang tepat. Pendekatan pembelajaran adalah cara melihat suatu masalah dalam pembelajaran yang memunculkan suatu pola sikap maupun perbuatan dalam mengatasi masalah yang muncul tersebut. Pendekatan yang akan digunakan dalam upaya meningkatkan hasil belajar siswa yang merosot adalah pendekatan kontekstual. Pada dasarnya diterapkannya pendekatan pembelajaran kontekstual bermaksud menata nalar, membentuk sikap siswa, dan menumbuhkan kemampuan menerapkan melalui pengalaman langsung. Ini berarti dalam proses pembelajaran tidak cukup bila hanya memberi tekanan pada kemampuan siswa mengerjakan soal. Sebagai seorang pengajar dan pendidik, guru juga harus memperhatikan bagaimana pemikiran siswa dapat terbentuk serta kemampuan mereka menerapkan pembelajaran, karena hal itu merupakan penopang penting terbentuknya hasil belajar siswa. Bertitik tolak dari latar belakang masalah yang ada peneliti ingin melakukan penelitian tindakan kelas dengan judul "Upaya Meningkatkan Hasil Belajar Siswa dengan Menerapkan Pendekatan Kontekstual dalam Pembelajaran IPA pada Materi Pokok Bioteknologi di Kelas IX-1 SMP Negeri 5 Stabat T.P. 2016/2017”.

\section{Perumusan Masalah}

Berdasarkan latar belakang masalah di atas, maka rumusan masalah dalam penelitian ini adalah: Apakah penerapan pembelajaran kontekstual dapat meningkatkan hasil belajar siswa pada pembelajaran IPA materi pokok bioteknologi di kelas IX-1 SMP Negeri 5 Stabat T.P. 2016/2017.

\section{Tujuan Penelitian}

Tujuan dari penelitian ini adalah untuk mengetahui peningkatkan hasil belajar siswa melalui penerapan pendekatan kontekstual pada pembelajaran IPA materi pokok bioteknologi di kelas IX-1 SMP Negeri 5 Stabat T.P. 2016/2017. 
Rusli : Upaya Meningkatkan Hasil Belajar Siswa Dengan Menerapkan Pendekatan Kontekstual Dalam Pembelajarn IPA Pada Materi Pokok Bioteknologi di Kelas XI-1 SMP N 5 Stabat 2016/17

\section{Manfaat Penelitian}

1. Manfaat teoritis yang diharapkan dari hasil penelitian ini adalah : hasil penelitian ini diharapkan dapat bermamfaat bagi penelitian selanjutnya agar muncul teori-teori atau pengetahuan baru.

2. Manfaat praktis yang diharapkan dari hasil penelitian ini adalah :

a. Bagi siswa

1) Sebagai pendukung belajar agar siswa bergairah dalam belajar sehingga meningkatkan minat dan motivasi belajar siswa

2) Meningkatkan hasil belajar siswa

3) Mendekatkan siswa dengan lingkungan di sekitarnya sehingga memberikan pengalaman berarti bagi siswa

4) Meningkatkan keaktifan siswa dalam kegiatan belajar mengajar

b. Bagi Guru :

1) Sebagai alat untuk memecahkan masalah yang ditemukan di kelas sehingga dapat merencanakan dan melakukan inovasi dalam mengatasi berbagai permasalahan pembelajaran yang dihadapinya.

2) Meningkatkan kualitas belajar mengajar yang di kelola guru

3) Sebagai salah satu syarat dalam usulan kenaikan pangkat IV/B

c. Bagi sekolah

4) Pentingnya penelitian ini bagi sekolah akan menjadi tolak ukur dalam peningkatan dan perbaikan mutu pembelajaran IPA di sekolah

\section{METODE PENELITIAN}

Jenis penelitian ini adalah penelitian tindakan kelas (Classroom Action Reseach), dimaksudkan untuk meningkatkan hasil belajar IPA siswa kelas IX-1 SMP Negeri 5 Stabat. Maka dalam desain penelitian ini memiliki tahapan-tahapan seperti yang dikemukakan Arikunto dkk dalam komplikasi penelitian tindakan kelas, ada 4 tahapan penelitian tindakan kelas, yaitu merencanakan, melaksanakan, mengamati dan refleksi.

\section{Siklus I}

1. Tahap Persiapan/Perencanaan Tindakan I, meliputi:

(a) Menyusun perangkat-perangkat pembelajaran, berupa RPP dengan pelajaran IPA materi pokok bioteknologi dengan penerapan pendekatan kontekstual.

(b) Mempersiapkan materi ajar dengan materi pokok bioteknologi

(c) Menyusun instrumen penelitian (tes kognitif hasil belajar siswa bentuk tes pilihan ganda, format lembar pengamatan ranah afektif, dan format lembar penilaian ranah psikomotorik).

(d) Menyiapkan alat dan bahan untuk keperluan pembelajaran

(e) Menyiapkan lembar observasi yang akan digunakan dalam penelitian.

(f) Mempersiapkan pembagian kelompok siswa

2. Pelaksanaan Tindakan I

Pelaksanaan tindakan I meliputi :

(a) Pelaksanaan tindakan I dengan melakukan tes awal untuk mengetahui kemampuan awal siswa.

(b) Guru mengajak siswa mengamati produk-produk bioteknologi yang ada di kehidupan sehari-hari

(c) Guru menjelaskan secara singkat materi pokok bioteknologi

(d) Guru membagikan LKS pada masing-masing kelompok siswa 
Rusli : Upaya Meningkatkan Hasil Belajar Siswa Dengan Menerapkan Pendekatan Kontekstual Dalam Pembelajarn IPA Pada Materi Pokok Bioteknologi di Kelas XI-1 SMP N 5 Stabat 2016/17

(e) Guru meminta setiap kelompok mengamati dan mengidentifikasi mikroorganisme apa saja yang terlibat dalam pembuatan produk bioteknologi tersebut. Selanjutnya, setiap kelompok akan mempresentasekan hasil diskusi mereka dihadapan kelompok lain.

(f) Guru membimbing siswa selama proses diskusi pembelajaran berlangsung

3. Observasi dan Interpretasi Tindakan

Observasi dan Interpretasi Tindakan siklus I meliputi :

Setiap kegiatan yang dilakukan siswa, baik di lapangan maupun diskusi, guru dan observer (teman sejawat) harus senantiasa mengamati kegiatan siswa dengan penilaian pribadi atau kelompok berdasarkan item pada lembar observasi, pada tahap ini peneliti melihat tinggi rendahnya pemahaman siswa yang berguna untuk melihat hasil yang dicapai oleh siswa. Lalu data hasil pengamatan langsung diinterpretasikan sehingga dapat dicari solusi perbaikan pada siklus berikutnya.

4. Analisis dan Refleksi Tindakan I

Berdasarkan hasil analisis data baik kognitif maupun non-kognitif, serta lembar observasi siswa terhadap pembelajaran kontekstual yang diterapkan guru, maka selanjutnya guru dan obsever melakukan evaluasi keberhasilan dan kendala-kendala yang dihadapi pada siklus I untuk diperbaiki pada siklus II.

\section{Siklus II}

\section{Perencanaan Tindakan II}

Berdasarkan hasil analisis dan refleksi siklus I, maka akan diketahui besarnya pencapaian tujuan yang diharapkan. Tindakan lanjutan lebih menekankan pada hal-hal yang belum tercapai pada siklus I. Tindakan pada siklus II direncanakan adalah : Menyusun perangkatperangkat pembelajaran, berupa RPP baru sesuai dengan hal-hal yang belum tercapai di siklus I. Pada siklus ke II ini guru menggunakan metode diskusi namun dengan pola yang berbeda.

2. Pelaksanaan Tindakan II

Pada siklus II, kegiatan pembelajaran divariasikan dengan penerapan metode diskusi, dimana guru mengarahkan masing-masing perwakilan kelompok yang dianggap mampu akan dikirim ke kelompok lain untuk mempresentasekan hasil pengamatan kelompoknya kemudian masing-masing kelompok memasangkan mikroorganisme yang tepat pada produk yang dihasilkan.

3. Observasi dan Interpretasi Tindakan II

Selama berlangsungnya proses pembelajaran dengan metode diskusi, observer melakukan pengamatan dengan mengisi lembar aktivitas siswa.

4. Analisis dan Refleksi Tindakan II

Setelah selesai siklus II, dilakukan analisis data penelitian secara keseluruhan. Apabila hasil belajar siswa meningkat maka peneliti dan teman sejawat memutuskan untuk tidak melakukan siklus ke III.

\section{KESIMPULAN DAN SARAN \\ 1. Kesimpulan}

1. Perolehan hasil belajar siswa kelas IX-1 pada tes awal menunjukkan nilai rata-rata kelas 34,75 dengan jumlah persentase ketuntasan klasikal hanya mencapai $17 \%$.

2. Pada tindakan siklus I dengan menggunakan pendekatan kontekstual diperoleh nilai rata-rata 74 dengan persentase ketuntasan klasikal sebanyak $53 \%$.

3. Pada tindakan siklus II dengan penerapan pendekatan kontekstual diperoleh nilai rata-rata kelas semakin meningkat yaitu 83,12 jumlah persentase ketuntasan klasikal juga mengalami kemajuan hingga mencapai $87,5 \%$. 
Rusli : Upaya Meningkatkan Hasil Belajar Siswa Dengan Menerapkan Pendekatan Kontekstual Dalam Pembelajarn IPA Pada Materi Pokok Bioteknologi di Kelas XI-1 SMP N 5 Stabat 2016/17

4. Dengan penerapan pendekatan kontekstual dapat meningkatkan hasil belajar siswa pada materi pokok bioteknologi di kelas IX SMP Negeri 5 Stabat T.P. 2016/2017.

\section{Saran}

Berdasarkan temuan peneliti, maka saran yang dapat diajukan yaitu :

1. Kepada Guru, berdasarkan hasil penelitian untuk aspek kognitif siswa, perolehan nilai siswa meningkat setelah dilakukan tindakan pada siklus II. Berarti pembelajaran kontekstual dapat mengembangkan kemampuan intelektual siwa. Oleh karena itu, penerapan pendekatan kontekstual dalam Kegiatan Belajar Mengajar (KBM) di sekolah dapat dikembangkan secara eksploratif, terlebih bila dipadukan dengan aneka pembelajaran yang lebih menarik dan menyenangkan, sehingga kemampuan kognitif siswa akan semakin baik.

2. Kepada siswa diharapkan untuk lebih aktif lagi dalam pembelajaran, siswa tampak senang dan menikmati pembelajaran langsung di lapangan, namun siswa masih enggan untuk bertanya kepada guru atau pengamat.

3. Kepada Kepala Sekolah hendaknya menghimbau kepada guru untuk memanfaatkan lingkungan sekitar sebagai sarana pembelajaran karena dapat memberikan makna yang berarti bagi pengalaman belajar siswa, mereka juga dapat lebih mudah memahami pelajaran yang diterima nantinya, siswa akan lebih mampu mengembangkan kemampuan intelektualnya ketika mereka mengalami langsung, tidak monoton diberikan teori yang sulit mereka pahami.

4. Pada peneliti selanjutnya yang ingin melakukan penelitian yang sama, hendaknya memperbaiki tahapan-tahapan yang ada sehingga mendapatkan hasil yang lebih baik

\section{DAFTAR PUSTAKA}

Hubbard L Ron, 2002, Pedoman Praktis Keterampilan Belajar, Jakarta : Grasindo.

Irwanto, 1997, Psikologi Umum. Jakarta : PT. Gramedia Pustaka Utama.

Johnson EB, 2007, Contextual Teaching and Learning, Mizan Learning Center, Bandung.

Muhibbin Syah, 2000, Psikologi Pendidikan dengan Suatu Pendekatan baru. Bandung:PT. Remaja Rosdakarya.

Mulyasa E, 2004, Kurikulum Berbasis Kompetensi, Remaja Rosda Karya, Bandung.

Nasution, 2000, Didaktik Asas-Asas Mengajar. Jakarta: Bumi Aksara.

Rohayati Dede, 2012, Penerapan Pendekatan Contextual Teaching Learning (CTL) untuk meningkatkan Hasil Belajar Siswa Pada Pembelajaran IPA Tentang Pengaruh Gaya Terhadap Benda Diambil dari http://repository.upi.edu,

Slameto, 2003, Belajar dan Faktor-Faktor yang Mempengaruhinya.Jakarta: Rineka Cipta.

Sulaeman M, 2004, Sains Untuk SD Kelas II, Jakarta : PT. Setia Purna Inves.

Trianto, 2007, Model pembelajaran terpadu dalam teori dan praktek. Jakarta: Prestasi Pustaka 